\title{
Implementasi Pull Message dengan menggunakan Restful Web Service pada komunikasi Wireless Sensor
}

\author{
Rakhmad Arif Hidayatullah a, Zamah Sari ${ }^{b}$, Mahar Faiqurahman ${ }^{c}$ \\ $a, b, c$ Teknik Informatika, Universitas Muhammadiyah Malang, Malang, Indonesia \\ email:akusuma.wahyu.a@gmail.com, babdzamahsari@gmail.com,cmaharf@gmail.com
}

\begin{tabular}{l}
\hline I N F O A R T I K E L \\
\hline Sejarah artikel: \\
Menerima 25 Januari 2017 \\
Revisi 4 Mei 2017 \\
Diterima 24 Januari 2018 \\
Online 15 Februari 2018 \\
\hline Kata kunci: \\
Arduino \\
Pull Message \\
Restful Web Service \\
Wireless Sensor Network \\
\hline
\end{tabular}

Keywords: Arduino Pull Message Restful Web Service Wireless Sensor Network

\begin{abstract}
A B S T R A K
Wireless Sensor Network (WSN) merupakan jaringan dengan skalabilitas yang sangat tinggi, dan memiliki jumlah sensor node yang sangat banyak. Untuk efisiensi biaya, sensor node banyak diterapkan dengan menggunakan Arduino. Arduino merupakan papan rangkaian elektronik open source yang di dalamnya terdapat chip mikrokontroler. Dengan keterbatasan resource yang dimiliki oleh Arduino, efisiensi komputasi yang ada di dalam sensor node harus diperhatikan. Salah satunya berkaitan dengan proses komunikasi dan pengiriman data dari sensor node ke sink node (gateway). Restful web service merupakan salah satu protokol komunikasi yang memanfaatkan HTTP. Protokol ini dikenal memiliki efisiensi yang cukup tinggi, di samping karena interoperabilitasnya untuk digunakan pada berbagai platform. Dalam makalah ini akan diuraikan hasil dari implementasi model pull message dengan menggunakan restful web service, pada komunikasi antara sink node (gateway) dengan sensor node, di dalam infrastruktur WSN. Dalam penelitian yang dilakukan, digunakan mikrokontroler Arduino sebagai sensor node, dan Raspberry Pi sebagai sink node. Selain itu juga diimplementasikan mekanisme thread untuk menangani multi-process yang berjalan di dalam sensor node. Hasil dari pengujian menunjukan bahwa interval sensing, ukuran data, dan jumlah sink node yang melakukan request, tidak begitu berpengaruh terhadap ketersedian free memory heap pada sensor node. Sedangkan ukuran dari data hasil sensing yang dikirim mempunyai pengaruh terhadap request-response time.
\end{abstract}

\section{A B S T R ACT}

Style APA dalam mensitasi
artikel ini:
Hidayatullah, R. A., Sari, Z.,
\& Faiqurahman, M. (2017).
Implementasi Pull Message
dengan menggunakan
Restful Web Service pada
komunikasi Wireless Sensor.
Register: Jurnal Ilmiah
Teknologi Sistem Informasi,
3(2), 65-74.




\section{Pendahuluan}

Wireless Sensor Network (WSN) merupakan suatu infrastruktur jaringan nirkabel yang terdiri dari beberapa node yang dapat bertindak sebagai sensor maupun sebagai sink (gateway). Sensor node bertanggung jawab di dalam pengambilan data dari lingkungan, sedangkan sink node bertindak sebagai pengumpul data dari sensor node untuk dikirimkan ke server database atau pengolah data. Teknologi WSN dapat digunakan untuk memonitor beberapa hal seperti temperatur, kelembapan, jarak benda, cahaya dan lain sebagainya dan digunakan untuk tujuan tertentu. Beberapa penerapan WSN yang digunakan untuk sistem monitoring, diantaranya adalah penggunaan WSN untuk monitoring greenhouse (Sawidin, Melo, \& Marsela, 2015; Chaudhary, Nayse, \& Waghmare, 2011), monitoring nutrisi air pada aquaponik (Maarif, 2016), dan monitoring kondisi lingkungan (Ferdoush \& Li, 2014).

Dalam implementasinya saat ini, pengembangan WSN banyak yang memanfaatkan board mikrokontroler yang bersifat Open Source, diantaranya adalah Arduino. Arduino ini memiliki beberapa keunggulan, diantaranya adalah harga perangkat yang tidak terlalu mahal, dan dapat diintegrasikan dengan beberapa modul hardware yang lain, termasuk modul sensor (Georgitzikis, Akribopoulos, \& Chatzigiannakis, 2012). Arduino ini juga memiliki kemampuan yang cukup baik untuk menjalankan proses sensing dan pengiriman data hasil sensing. Beberapa penelitian sebelumnya yang memanfaatkan Arduino sebagai sensor node diantaranya adalah pada sistem monitoring kondisi lingkungan dengan memanfaatkan WSN (Ferdoush \& Li, 2014). Selain itu terdapat penelitian lain yang juga memanfaatkan Arduino yaitu pada sistem WSN untuk monitoring suhu dan kelembaban (Barroca, et al., 2013).

Karena resource yang dimiliki oleh sensor node yang berbasis Arduino sangat terbatas, maka komputasi yang terdapat di dalamnya harus efisien. Termasuk komputasi yang berkaitan dengan proses komunikasi antar node dan antara sensor node dengan sink node. Selain itu permasalahan interoperabilitas komunikasi juga menjadi tantangan dalam pengembangan WSN dengan resource yang terbatas. Beberapa penelitian telah dilakukan sebelumnya terkait dengan mekanisme komunikasi antar node dalam WSN. Othman, Glitho, \& Khendek (2007) dalam penelitiannya telah mengimplementasikan SOAP Web Service framework untuk mekanisme komunikasi antar node. Hasil dari penelitian tersebut menunjukan bahwa penggunaan web service dapat meningkatkan interoperabilitas komunikasi, namun kurang efisien dalam penggunaan resource yang ada pada tiap node. Sementara pada penelitian yang lain dikembangkan suatu model Multi-level SOA yang dapat mengefisiensikan komunikasi berdasarkan pada sumber daya hardware yang dimiliki oleh sensor node (Leguay, Lopez-Ramos, Jean-Marie, \& Conan, 2008). Sedangkan Kabisch dalam makalahnya memaparkan efisiensi dari penggunaan format data XML untuk pertukaran data dalam WSN (Käbisch, Peintner, Heuer, \& Kosch, 2010).

Restful Web Service merupakan salah satu teknologi web service yang memanfaatkan protokol HTTP untuk pertukaran datanya. Restful Web Service banyak digunakan saat ini, karena selain mendukung interoperabilitas seperti Web Service lainnya, juga mempunyai efisiensi komunikasi yang tinggi. Pada penelitian yang telah dilakukan (Hamad, Saad, \& Abed, 2010), disebutkan bahwa Restful Web Service ini sangat baik diimplementasikan pada hardware yang memiliki resource terbatas seperti pada perangkat mobile. Dengan sifat dari Restful yang stateless seperti halnya HTTP request-response, serta memiliki ukuran data yang cukup kecil, Web Service ini dapat menghemat penggunaan resource komputasi untuk proses pengiriman data.

Pola dari pengiriman data juga berpengaruh terhadap penggunaan resource pada sensor node. Secara garis besar, pola pengiriman data dibagi menjadi dua, yaitu push message dan pull message. Push message akan dikirimkan secara langsung oleh penyedia data ke client yang membutuhkan data tanpa didahului oleh proses permintaan data dari client tersebut. Sedangkan pada pull message, data akan diberikan oleh penyedia data hanya ketika ada permintaan data dari client. Dari penelitian yang telah dilakukan sebelumnya (Burgstahler, Lampe, Richerzhagen, \& Steinmetz, 2013), didapatkan bahwa pada kasus tertentu model push-message memiliki efisiensi yang lebih rendah dalam penggunaan sumber daya, dibandingkan dengan pull-message. Hal ini disebabkan karena pada push message, koneksi antara sumber data dengan client yang membutuhkan data dibuka secara terus menerus, meskipun client tidak sedang memerlukan data. Sedangkan pada pull message, koneksi dilakukan hanyak ketika client membutuhkan data dari sumber data. 
Dalam makalah ini dibahas mekanisme pull message yang diimplementasikan dengan menggunakan Restful Web Service sebagai protokol komunikasi antara sensor node dan sink node. Dalam penelitian yang dilakukan, digunakan mikrokontroler Arduino untuk implementasi sensor node dan Raspberry Pi untuk implemetasi sink node. Proses pull message diinisiasi oleh beberapa sink node yang melakukan permintaan data hasil sensing ke sensor node. Sehingga setiap sensor node harus dapat menangani permintaan oleh beberapa sink node dalam satu waktu.

\section{Metode Penelitian}

\subsection{Arsitektur system}

Arsitektur sistem yang dibangun dapat dilihat pada Gambar 1, terdiri dari beberapa komponen utama, yaitu sensor node yang diimplementasikan menggunakan Arduino dan sink node yang diimplementasikan menggunakan Rapsberry Pi. Sensor node bertanggung jawab untuk melakukan proses sensing (mengambil data dari lingkungan dengan menggunakan sensor), dan mengirimkan data hasil sensing ketika sink node melakukan proses pull-message. Sedangkan sink node bertanggung jawab untuk mengumpulkan data hasil sensing dari sensor node melalui mekanisme pull message. Proses pull message ini dilakukan ketika sink node membutuhkan data hasil dari proses sensing. Data ini selanjutnya akan dikirimkan oleh sink node ke server untuk diolah. Karena penelitian yang dilakukan berfokus pada komunikasi antara sensor node dengan sink node menggunakan mekanisme pull-message, maka segala hal yang berkaitan dengan proses pengolahan data yang ada di server, serta komunikasi antara sink node dengan server diasumsikan tidak dibahas dalam sistem.

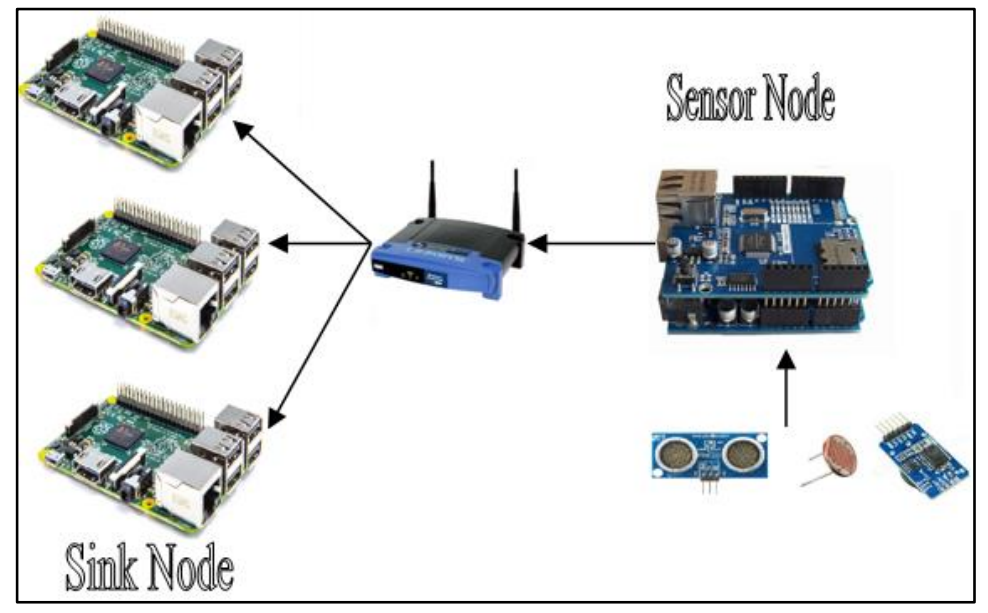

Gambar 1. Arsitektur sistem

Mekanisme komunikasi antara sensor node dengan sink node dilakukan melalui medium nirkabel dengan perantara access point. Satu buah sensor node dapat terkoneksi dengan beberapa buah sink node yang akan melakukan proses pull-message data hasil sensing. Hal ini berdasarkan asumsi bahwa data hasil sensing yang dimiliki oleh suatu sensor node, dibutuhkan oleh beberapa sink node. Protokol Restful Web Service digunakan selama proses komunikasi berlangsung antara sensor node dengan sink node. Di dalam sensor node terdapat HTTP server sederhana yang dapat menerima request data hasil sensing dari sink node, dengan menggunakan mekanisme pull message. Respon yang berisi data hasil sensing diberikan oleh sensor node dalam format Restful. Karena interval waktu proses pull message yang dilakukan oleh beberapa sink node diasumsikan tidak terjadi secara tetap, maka sensor node perlu menyimpan data hasil sensing selama beberapa waktu di dalam memori internal, sampai data tersebut diambil oleh semua sink node.

\subsection{Perancangan hardware untuk sensor node dan sink node}

Komponen hardware dalam sistem yang dibangun terdiri dari Arduino, Raspberry Pi, dan Wireless Access Point (WAP). Mikrokontroller Arduino digunakan sebagai sensor node yang melakukan proses sensing dengan menggunakan sensor. Raspberry Pi digunakan sebagai sink node yang mengumpulkan 
data dari sensor node melalui mekanisme pull-message. Sedangkan WAP digunakan sebagai perantara komunikasi antara sensor node dengan sink node. Dalam penelitian ini digunakan WAP agar satu buah sensor node dapat menerima koneksi lebih dari satu sink node yang membutuhkan data hasil sensing.

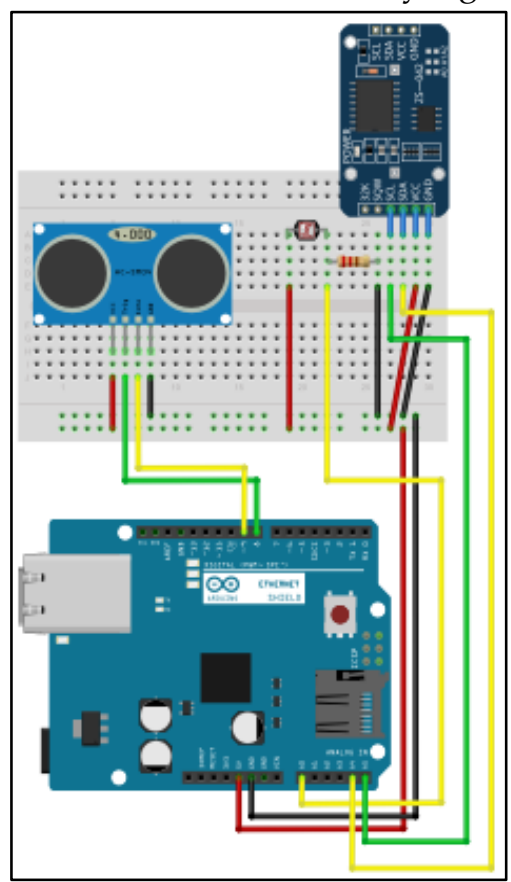

Gambar 2. Sensor node

Skema hardware untuk sensor node dapat dilihat pada Gambar 2. Arduino yang merupakan komponen utama dari sensor node terhubung dengan modul sensor. Karena fokus penelitian terdapat pada mekanisme komunikasi antara sensor node dengan sink node, maka dalam penelitian yang dilakukan diasumsikan digunakan sensor cahaya Light Dependent Resistor (LDR), dan sensor jarak (ultrasonic). Sensor yang digunakan tersebut terhubung dengan port GPIO dari Arduino, dan beberapa port lain seperti power dan GND. Selain itu terdapat modul real time clock (RTC) yang terhubung dengan pin SLC dan SDA atau pin A5 dan A4 pada Arduino. Fungsi dari modul RTC adalah untuk menangani pewaktuan pada sistem yang dapat menghasilkan current time yang digunakan dalam pencatatan data hasil sensing. Selain itu, di Arduino juga terdapat modul ethernet shield yang digunakan untuk koneksi dengan WAP. SD card yang terdapat pada Ethernet Shield dapat dimanfaatkan untuk menyimpan data hasil sensing, sehingga dapat mengatasi keterbatasan penyimpanan yang terdapat pada Arduino.

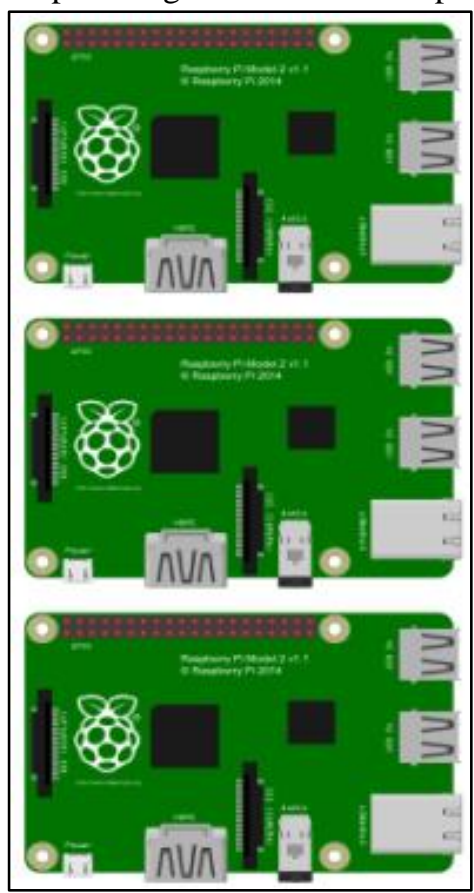

Gambar 3. Sink node (gateway) 
Skema hardware dari sink node dapat dilihat pada Gambar 3. Sink node yang juga berperan sebagai gateway diimplementansikan dengan menggunakan Raspberry Pi. Dalam penelitian ini dipilih Raspberry Pi untuk sink node, karena proses yang berjalan di dalam sink node tidak terlalu kompleks, dan membutuhkan storage yang besar. Sink node ini terkoneksi dengan sensor node dengan menggunakan jaringan nirkabel, melalui modul Wi-Fi yang terdapat pada Raspberry Pi. Sedangkan LAN port dari Raspberry Pi, terkoneksi dengan jaringan kabel ke server pengolah data. Namun dalam penelitian ini diasumsikan bahwa koneksi dari Rapsberry Pi ke server pengolah data, dan proses yang ada di pengolah data tidak dibahas. Di dalam Raspberry Pi, segala data sensor hasil permintaan ke sensor node akan disimpan ke dalam SD card. Data ini kemudian akan dikirimkan ke server untuk diolah.

\subsection{Proses sensing dan penanganan Pull Message}

Proses yang terdapat pada sensor node di Arduino dibagi menjadi dua bagian utama, yaitu proses yang menangani sensing untuk mengambil data dari lingkungan, dan proses untuk menerima permintaan data melalui mekanisme pull message dari sink node. Kedua proses tersebut dikerjakan secara paralel, di mana sensor node dapat menerima dan melayani proses pull message dari sink node pada waktu sensor node sedang melakukan proses sensing. Demikian juga untuk penanganan proses pull message, dalam sekali waktu sensor node juga dapat menangani proses pull message dari beberapa sink node sekaligus.

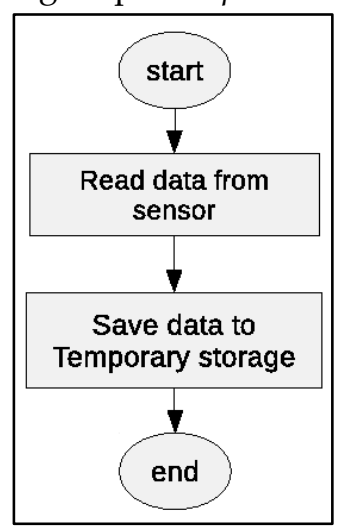

Gambar 4. Proses sensing pada sensor node

Mekanisme sensing yang terdapat pada sensor node dapat dilihat pada Gambar 4. Dalam proses sensing dilakukan pembacaan sensor LDR dan ultrasonic secara periodik. Proses pembacaan sensor LDR dan ultrasonic dilakukan secara berurutan. Setelah proses pembacaan data oleh sensor dilakukan, selanjutnya data disimpan dalam temporary storage yang berupa SD card yang terdapat di dalam modul Ethernet Shield sebagai unit penyimpanan lokal. Dengan memanfaatkan SD card ini data hasil sensing yang dapat ditampung semakin banyak.

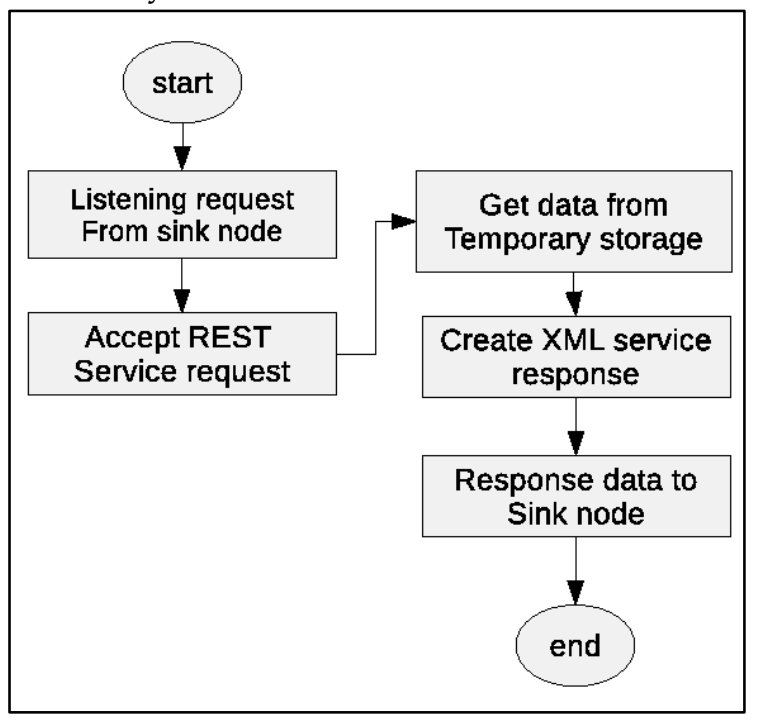

Gambar 5. Proses penanganan pull-message request dari sink node 
Gambar 5 menunjukan proses penanganan request data dari sink node melalui mekanisme pullmessage. Request data diterima oleh sensor node dalam bentuk REST service request melalui protokol HTTP. Sehingga untuk menangani request tersebut, di dalam sensor node diimplementasikan HTTP server yang terus berjalan melakukan proses listening permintaan data dari sink node. Ketika menerima request, HTTP server ini akan mengembalikan response kepada sink node berupa data hasil sensing dalam format XML service response. Data hasil sensing yang dikirimkan tersebut ini tidak langsung didapatkan dari modul sensor secara real time, akan tetapi diambil dari temporary storage yang terdapat pada $S D$ card di dalam modul Ethernet Shield. Hal ini dilakukan karena semua data hasil sensing ditampung terlebih dahulu di dalam temporary storage tersebut.

Di dalam sensor node juga diimplementasikan thread. Thread ini digunakan untuk menangani eksekusi beberapa proses yang ada dalam sensor node agar dapat berjalan secara paralel. Proses yang ditangani oleh thread diantaranya adalah proses sensing dan proses-proses yang terdapat pada web server seperti proses listening request dan proses response data hasil sensing. Dikarenakan secara hardware, unit pemrosesan data yang terdapat pada Arduino tidak mendukung thread, maka pemrosesan thread dilakukan dengan konsep time slicing, di mana beberapa proses akan dieksekusi secara bergantian sesuai dengan interval waktu tertentu.

\subsection{Proses Pull Message}

Proses pull message merupakan proses permintaan data sensor oleh sink node ke sensor node, dengan cara mengirimkan pesan request ke sensor node, dan setelah itu sink node akan menerima response berupa data sensor dari sensor node. Gambar 6 menunjukan proses pull message yang terdapat pada sink node. Seperti yang dijelaskan pada Gambar 6, ketika sink node menginginkan data hasil sensing, maka sink node akan mengirimkan REST service request kepada pada sensor node, dengan menyertakan informasi log waktu data hasil sensing terakhir kali didapatkan. Informasi waktu ini nantinya digunakan oleh sensor node untuk menentukan data manakah yang akan dikirim ke sink node. Dengan mekanisme seperti ini, sensor node tidak perlu mengirimkan semua data hasil sensing yang disimpan di dalam SD card, akan tetapi cukup mengirimkan data terbaru yang belum didapatkan oleh sink node. Setelah mendapatkan response dari sensor node dalam format XML, sink node akan melakukan parsing pada data response tersebut dan memasukannya ke dalam database yang terdapat pada sink node. Data ini selanjutnya akan dikirimkan ke server untuk diolah.

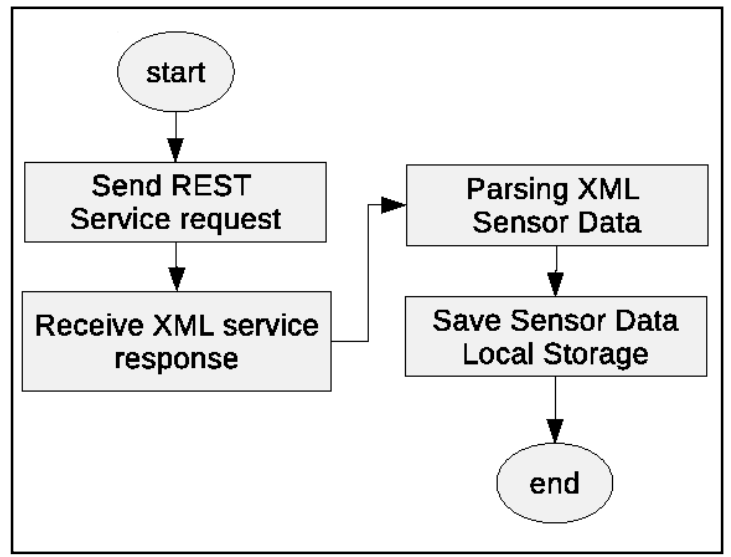

Gambar 6. Proses pull message pada sink node

\section{Hasil Penelitian dan Pembahasan}

Setelah mekanisme pull message dengan menggunakan Restful Web Service berhasil diimplementasikan di dalam proses komunikasi antara sensor node yang berbasis Arduino, dan sink node yang berbasis Raspberry Pi, maka dilakukan pengujian terhadap sistem wireless sensor tersebut. Pengujian dilakukan untuk mengetahui performa dari sensor node yang dipengaruhi oleh beberapa parameter pengujian. Karena keterbatasan fitur pada monitoring sistem yang terdapat di Arduino, maka ukuran performa dari Arduino dilihat dari banyak sedikitnya memory heap yang tersisa di dalam Arduino selama 
menjalankan proses komputasi. Ada beberapa skenario pengujian yang dilakukan, yaitu: pengujian untuk mengetahui pengaruh ukuran data yang dikirim pada mekanisme pull message terhadap memory heap yang tersisa, pengujian untuk mengetahui pengaruh jumlah sink node yang melakukan request terhadap memory heap yang tersisa, dan pengujian pengaruh besar data terhadap waktu request-response pada mekanisme pull message.

\subsection{Pengujian pengaruh ukuran data pada pull message terhadap memory heap}

Pengujian ini dilakukan pada sensor node. Ukuran data yang dikirim oleh sensor node ke sink node melalui pull message tergantung dari seberapa sering sensor node melakukan proses sensing (interval waktu sensing). Tujuan pengujian ini untuk mengetahui apakah ukuran data sensor yang dikirim sebagai response ke sink node di dalam mekanisme pull message, akan berpengaruh terhadap memory heap yang tersisa di sensor node. Pencatatan memory heap yang tersisa dilakukan oleh thread tersendiri yang berjalan secara paralel dengan proses pengiriman response di dalam mekanisme pull message. Skenario pengujian ini dengan dilakukan beberapa percobaan proses pull data hasil sensing oleh sink node dengan variasi ukuran data yg berbeda, dimulai dari $10 \mathrm{~KB}, 20 \mathrm{~KB}, 30 \mathrm{~KB}, 40 \mathrm{~KB}, 50 \mathrm{~KB}, 60 \mathrm{~KB}, 70 \mathrm{~KB}, 80 \mathrm{~KB}, 90 \mathrm{~KB}$, dan 100 KB. Hasil pengujian dapat dilihat pada Tabel 1 dan Gambar 7.

\begin{tabular}{ccc} 
Tabel 1. Hasil pengujian pengaruh ukuran da \\
\cline { 2 - 3 } No. & $\begin{array}{c}\text { Ukuran Data } \\
\text { (Kilobyte) }\end{array}$ & $\begin{array}{c}\text { Free Memory } \\
\text { Heap }\end{array}$ \\
\hline 1 & 10 & 6148 \\
2 & 20 & 6148 \\
3 & 30 & 6148 \\
4 & 40 & 6148 \\
5 & 50 & 6148 \\
6 & 60 & 6148 \\
7 & 70 & 6148 \\
8 & 80 & 6148 \\
9 & 90 & 6148 \\
10 & 100 & 6148 \\
\hline
\end{tabular}

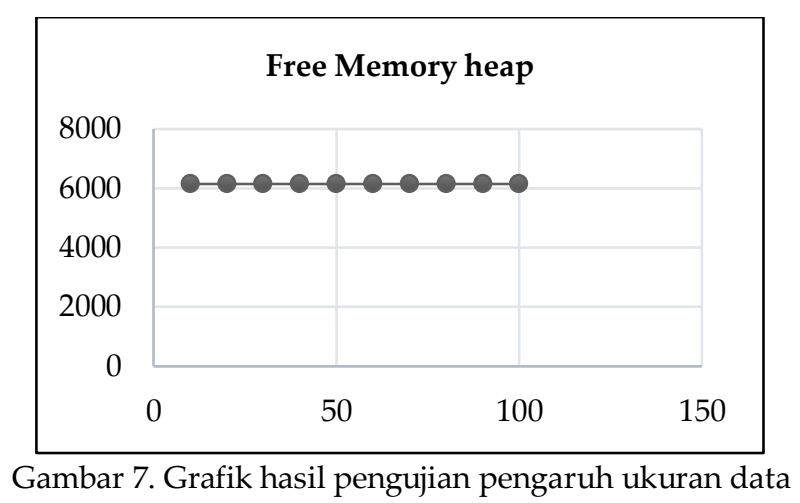

Hasil yang didapat dari pengujian ini dapat dilihat pada Gambar 7, dapat dilihat bahwa besarnya data yang dikirim tidak berpengaruh terhadap memory heap yang tersisa di dalam sensor node. Dari hasil analisis yang telah dilakukan, hal ini disebabkan karena tidak adanya mekanisme sinkronisasi dan penjadwalan thread menyebabkan proses pencatatan memory heap yang tersisa tidak dapat dilakukan pada waktu yang benar-benar bersamaan dengan proses pengiriman data response berlangsung. Sehingga ada kemungkinan nilai yang tercatat di hasil pengujian merupakan nilai memory heap yang tersisa pada saat sensor node (mikrokontroler Arduino) tidak sedang mengeksekusi proses pengiriman data response.

\subsection{Pengaruh jumlah sink node yang melakukan pull message terhadap memory heap}

Pengujian ini dilakukan pada sensor node. Tujuan pengujian ini untuk mengetahui pengaruh jumlah sink node (Raspberry Pi) yang melakukan request data dengan pull message terhadap memory heap yang tersisa 
pada sensor node (Arduino). Seperti pengujian sebelumnya, pencatatan memory heap yang tersisa dilakukan dengan menggunakan thread yang terpisah, akan tetapi berjalan secara paralel dengan thread yang menangani proses penerimaan request. Skenario pengujian dilakukan dengan cara melakukan variasi pada jumlah sink node yang melakukan request ke sensor node. Hasil pengujian ini dapat dilihat pada Tabel 2 dan Gambar 8.

Tabel 2. Hasil pengujian pengaruh jumlah sink node

\begin{tabular}{ccc}
\hline No. & $\begin{array}{c}\text { Jumlah sink } \\
\text { node }\end{array}$ & $\begin{array}{c}\text { Free Memory } \\
\text { Heap (bytes) }\end{array}$ \\
\hline 1 & 10 & 6148 \\
2 & 20 & 6148 \\
3 & 30 & 6148 \\
\hline
\end{tabular}

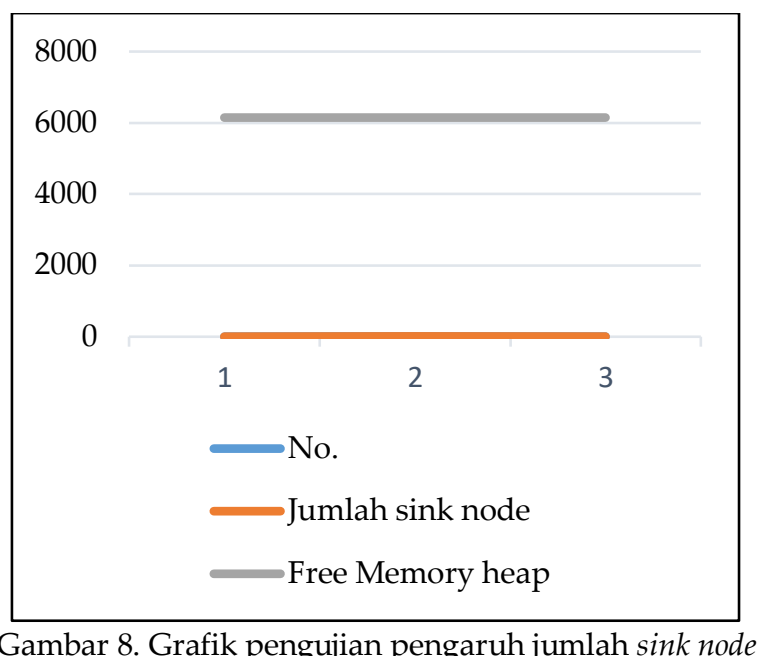

Hasil analisis yang didapat dari pengujian jumlah sink node terhadap memory heap yang tersisa, dapat dijelaskan bahwa jumlah atau banyaknya sink node yang melakukan request pada proses pull message tidak berpengaruh terhadap memory heap. Sama seperti pengujian sebelumnya, hal ini disebabkan karena tidak ada mekanisme sinkronisasi dan penjadwalan thread menyebabkan proses pencatatan memory heap yang tersisa tidak dapat dilakukan pada waktu yang benar-benar bersamaan dengan proses penerimaan request data dari beberapa sink node sekaligus .

\subsection{Pengujian pengaruh besar data terhadap pull message time}

Tabel 3. Tabel hasil pengujian waktu request dan response

\begin{tabular}{ccc}
\hline No. & $\begin{array}{c}\text { Ukuran Data } \\
\text { (Kilobyte) }\end{array}$ & Waktu (detik) \\
\hline 1. & 10 & 3 \\
2. & 20 & 6 \\
3. & 30 & 10 \\
4. & 40 & 13 \\
5. & 50 & 17 \\
6. & 60 & 20 \\
7. & 70 & 23 \\
8. & 80 & 26 \\
9. & 90 & 29 \\
10. & 100 & 33 \\
\hline
\end{tabular}

Pengujian ini dilakukan pada sink node. Tujuan pengujian ini dilakukan untuk mengetahui apakah besarnya data akan berpengaruh terhadap waktu request dan response pada proses pull message, yang dicatat oleh sink node. Skenario pada pengujian ini dilakukan melalui proses request (pull data sensor) yang dilakukan oleh sink node ke sensor node. Waktu yang dicatat adalah selisih waktu ketika sink node melakukan request, dan menerima response data dari sensor node. Dalam pengujian ini data yang 
dikirimkan dibuat bervariasi, yaitu ukuran data $10 \mathrm{~KB}, 20 \mathrm{~KB}, 30 \mathrm{~KB}, 40 \mathrm{~KB}, 50 \mathrm{~KB}, 60 \mathrm{~KB}, 70 \mathrm{~KB}, 80 \mathrm{~KB}$, 90 KB, dan 100 KB. Hasil pengujuan dapat dilihat pada Tabel 3 dan Gambar 9.

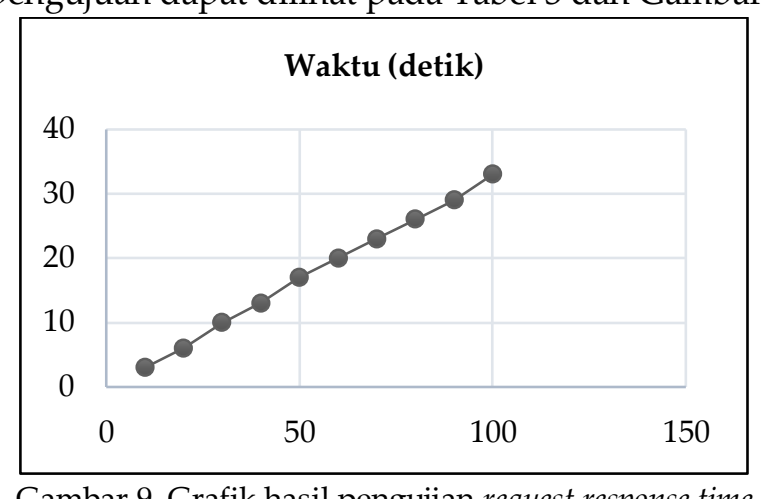

Gambar 9. Grafik hasil pengujian request response time

Hasil analisis yang didapat dari pengujian ini didapat bahwa terdapat jeda waktu yang berbeda antara proses pengiriman request data yang dilakukan oleh sink node, hingga menerima response data dari sensor node. Semakin besar ukuran data yang dipesan semakin besar jeda waktu proses request dan response. Dapat dilihat pada Gambar 9 bahwa kenaikan waktu proses request dan response terjadi secara linier sering dengan kenaikan jumlah data yang dipesan oleh sink node melalui proses pull message. Dari pengujian yang dilakukan juga didapatkan hasil bawah ketika proses penerimaan request dan pengiriman respon berjalan pada sensor node (Arduino), proses yang lain akan mengalami interupt. Proses terjadinya interupt dapat dilihat pada Gambar 10.

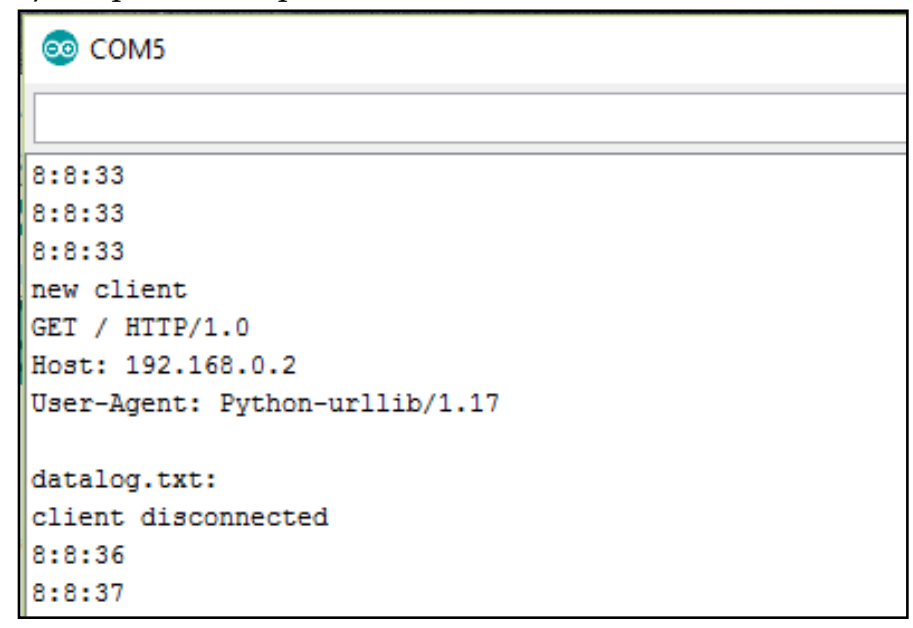

Gambar 10. Proses interupt yang terjadi pada sensor node

\section{Kesimpulan}

Berdasarkan hasil implementasi dan pengujian yang telah dilakukan pada penelitian ini maka didapatkan beberapa kesimpulan sebagai berikut:

1. Mekanisme pull message dengan menggunakan Restful Web Service dapat diimplementasikan pada proses komunikasi di dalam WSN. Sensor node (Arduino) dapat digunakan sebagai web server dan bisa menangani request dari banyak client melalui pemanfaatan thread sederhana, sedangkan sink node (Raspberry Pi) dapat melakukan proses pull message dengan menggunakan protokol Restful Web Service pada komunikasi WSN.

2. Memory heap yang tersisa digunakan untuk mengukur kinerja dari sensor node yang memanfaatkan metode pull message dengan protokol restful. Hasil pengujian didapat bahwa memory heap tidak terpengaruh dengan proses sensing, ukuran data, dan jumlah sink node dikarenakan tidak adanya mekanisme sinkronisasi dan penjadwalan thread. Sedangkan dalam pengujian waktu request dan response, ukuran data yang akan dikirim sangat berpengaruh terhadap waktu request dan response dari sink node ke sensor node. 
Hasil penelitian yang telah dilakukan masih jauh dari sempurna dan masih terdapat kekurangan. Diantaranya adalah masih tingginya waktu request-response antara sink node dengan sensor node. Untuk pengembangan penelitian berikutnya perlu untuk ditambahkan metode atau solusi yang dapat mengefisiensikan mekansime pull message (request-response data hasil sensing) sehingga waktu request dan response tidak terlalu berpengaruh siginifikan terhadap besarnya ukuran data hasil sensing yang dikirim.

\section{Referensi}

Barroca, N., M.Borges, L., J.Velez, F., Monteiro, F., Górski, M., \& Castro-Gomes, J. (2013). Wireless sensor networks for temperature and humidity monitoring within concrete structures. Construction and Building Materials, 40(2013), 1156-1166.

Burgstahler, D., Lampe, U., Richerzhagen, N., \& Steinmetz, R. (2013). Push vs. Pull: An Energy Perspective (Short Paper). Service-Oriented Computing and Applications (SOCA), 2013 IEEE 6th International Conference on (pp. 190-193). Koloa: IEEE.

Chaudhary, D. D., Nayse, S. P., \& Waghmare, L. M. (2011). Application of wireless sensor networks for greenhouse parameter control in precision agriculture. International Journal of Wireless $\&$ Mobile Networks (IJWMN), 3(1), 140-149.

Ferdoush, S., \& Li, X. (2014). Wireless Sensor Network System Design Using Raspberry Pi and Arduino for Environmental Monitoring Applications. Procedia Computer Science, 34(2014), 103-110.

Georgitzikis, V., Akribopoulos, O., \& Chatzigiannakis, I. (2012). Controlling Physical Objects via the Internet using the Arduino Platform over 802.15.4 Networks. IEEE Latin America Transactions, 10(3), 1686-1689.

Hamad, H., Saad, M., \& Abed, R. (2010). Performance Evaluation of RESTful Web Services for Mobile Devices. International Arab Journal of e-Technology, 1(3), 72-78.

Käbisch, S., Peintner, D., Heuer, J., \& Kosch, H. (2010). Efficient and Flexible XML-Based Data-Exchange in Microcontroller-Based Sensor Actor Networks. Advanced Information Networking and Applications Workshops (WAINA), 2010 IEEE 24th International Conference on (pp. 508-513). Perth: IEEE.

Leguay, J., Lopez-Ramos, M., Jean-Marie, K., \& Conan, V. (2008). An efficient service oriented architecture for heterogeneous and dynamic wireless sensor networks. Local Computer Networks, 2008. LCN 2008. 33rd IEEE Conference on (pp. 740-747). Montreal: IEEE.

Maarif, A. F. (2016). System Monitoring And Controlling Water Nutrition aquaponics Using Arduino Uno Based Web Server. Kinetik, 1(1), 39-46.

Othman, N. Y., Glitho, R. H., \& Khendek, F. (2007). The Design and Implementation of a Web Service Framework for Individual Nodes in Sinkless Wireless Sensor Networks. Computers and Communications, 2007. ISCC 2007. 12th IEEE Symposium on (pp. 941-947). Las Vegas: IEEE.

Sawidin, S., Melo, O. E., \& Marsela, T. (2015). Monitoring Kontrol Greenhouse untuk Budidaya Tanaman Bunga Krisan dengan LabView. JNTETI (Jurnal Nasional Teknik Elektro dan Teknologi Informasi), 4(4), 236-242. 